\title{
Lipid solubility as a factor influencing the activity of uncoupling phenols
}

Citation for published version (APA):

Hemker, H. C. (1962). Lipid solubility as a factor influencing the activity of uncoupling phenols. Biochimica et Biophysica Acta. Mucoproteins and Mucopolysaccharides, 63(1), 46-54. https://doi.org/10.1016/00063002(62) $90337-2$

Document status and date:

Published: 01/01/1962

DOI:

10.1016/0006-3002(62)90337-2

Document Version:

Other version

\section{Please check the document version of this publication:}

- A submitted manuscript is the version of the article upon submission and before peer-review. There can be important differences between the submitted version and the official published version of record.

People interested in the research are advised to contact the author for the final version of the publication, or visit the DOI to the publisher's website.

- The final author version and the galley proof are versions of the publication after peer review.

- The final published version features the final layout of the paper including the volume, issue and page numbers.

Link to publication

\footnotetext{
General rights rights.

- You may freely distribute the URL identifying the publication in the public portal. please follow below link for the End User Agreement:

www.umlib.nl/taverne-license

Take down policy

If you believe that this document breaches copyright please contact us at:

repository@maastrichtuniversity.nl

providing details and we will investigate your claim.
}

Copyright and moral rights for the publications made accessible in the public portal are retained by the authors and/or other copyright owners and it is a condition of accessing publications that users recognise and abide by the legal requirements associated with these

- Users may download and print one copy of any publication from the public portal for the purpose of private study or research.

- You may not further distribute the material or use it for any profit-making activity or commercial gain

If the publication is distributed under the terms of Article $25 \mathrm{fa}$ of the Dutch Copyright Act, indicated by the "Taverne" license above, 


\title{
LIPID SOLUBILITY AS A FACTOR INFLUENCING THE ACTIVITY OF UNCOUPLING PHENOLS ${ }^{\star}$
}

\author{
H. C. HEMKER \\ Laboratory of Physiological Chemistry University of Amsterdam (The Netherlands)
}

(Received March 27th, I962)

\begin{abstract}
SUMMARY
I. The effects of the $\mathrm{p} K$ and lipid solubility of a series of uncoupling phenols, including a homologous series of 2,6-dinitro-4-alkylphenols, and of the $\mathrm{pH}$ of the medium upon the ATPase activity of rat-liver mitochondria were tested.

2. The concentration of an uncoupling phenol required for the maximum activity of the latent ATPase $\left(c_{\mathrm{opt}}\right)$ is lower in a more acid medium and with a more lipophilic phenol. Within a homologous series the maximum ATPase activity induced is independent of the size of the alkyl substituent.

3. The equation $\mathrm{p} c_{1}=\mathrm{p} c_{\mathrm{aq}}+\mathrm{pH}+\mathrm{p} Q+\log \left(K+\left[\mathrm{H}^{+}\right]+f Q\left[\mathrm{H}^{+}\right]\right)$gives the relationship between the concentration $\left(c_{1}\right)$ of an uncoupling phenol in a lipid phase within the mitochondrion and the concentration $\left(c_{\mathrm{aq}}\right)$ in the surrounding aqueous phase, where $Q$ is the partition coefficient of the undissociated phenol molecule between lipid and water, $K$ is its acid dissociation constant, and $f$ is the ratio of volumes of lipid and aqueous phases. $\left(c_{1}\right)_{\text {opt }}$ is defined as $c_{1}$ when $c_{\text {aq }}$ is the concentration in the aqueous phase giving maximum ATPase activity $\left(\left(c_{\mathrm{aq}}\right)_{\mathrm{opt}}\right)$.

4. $\mathrm{p}\left(c_{1}\right)_{\text {opt }}$ was found to be independent of the size of the alkyl substituent in a. homologous series of alkyl-2,6-dinitrophenols, and to be a linear function of the $\mathrm{pH}$ of the medium.

5. Depending on the conditions, the above equation could be reduced to the limiting cases:

$$
\begin{aligned}
\text { I. } \mathrm{p} c_{1} & =\mathrm{p} c_{\mathrm{aq}}+\mathrm{p} Q+\mathrm{pH}-\mathrm{p} K \\
\text { II. } \mathrm{p} c_{1} & =\mathrm{p} c_{\mathrm{aq}}+\mathrm{pQ} \\
\text { III. } \mathrm{p} c_{1} & =\mathrm{p} c_{\mathrm{qq}}+\log f
\end{aligned}
$$
\end{abstract}

It could be shown that, under the experimental conditions where the limiting cases applied, the corresponding equations were followed. This gives support to the assumption that the uncoupling activity is directly determined not by the amount of phenol added to the medium, but by the amount dissolved in the mitochondrial lipid.

\section{INTRODUCTION}

It has long been known that the lipophilic character of a pharmacologically active substance may be one of the main factors influencing its activity in vivo, in the sense that the more lipophilic compound is the more active ${ }^{2}$. A similar correlation has alsobeen shown in experiments on isolated mitochondria, e.g. in the case of barbituric

* This work is part of the M.D. thesis of the author, which was published in April, I962 (see ref. I). 
acid derivatives ${ }^{3}, 4,2$-hydroxy-3-alkyl-I,4-naphthoquinones ${ }^{5,6}$, dicoumarol and similar compounds $s^{7,8}$, trialkyl tin compounds ${ }^{9}$ and blastomycinic acid derivatives ${ }^{6}$.

HÜLSMANN ${ }^{10}$ and GLADTKE AND LISS ${ }^{11,12}$ have stressed that the lipid solubility of an uncoupling phenol is an important factor in its effectiveness. Besides the wellknown stimulatory action of substituted phenols on mitochondrial ATPase and respiration ${ }^{13}$, these compounds have an inhibitory effect at higher concentrations, as has been reported by MYERs AND SLATER ${ }^{14}$ for ATPase and by HÜLSMANN ${ }^{10}$ for mitochondrial respiration. HÜLSMANN ${ }^{10}$ showed that the lipid-soluble 4-isoamyl-2,6dinitrophenol was a much more effective inhibitor than 2,6-dinitrophenol. Similarly, GLADTKE AND LISS ${ }^{11,12}$ showed that the uncoupling activity, i.e. stimulatory effect, of phenols was determined partly by the lipid solubility. This being the case, it is to be expected that the $\mathrm{p} K$ of the phenol and the $\mathrm{pH}$ of the medium are also important, as stressed by DE DEKEN ${ }^{15}$, MYers AND SLATER ${ }^{14}$ and PARKER ${ }^{16}$, since the ionized form (the phenolate ion) of such relatively simple compounds is almost insoluble in lipid.

In this paper, the effects of lipid solubility, $\mathrm{pH}$ and $\mathrm{pK}$ on the stimulatory and inhibitory effects of substituted phenols are studied quantitatively. Some of the results have been published in a preliminary form ${ }^{17}$.

\section{METHODS}

The rat-liver mitochondria were isolated as described by MYERS AND SLATER ${ }^{14}$. ATPase activity was determined by the procedure described by these authors ${ }^{14}$. The reaction medium contained $50 \mathrm{~m} M$ Tris $-\mathrm{HCl}$ buffer of the appropriate $\mathrm{pH}$, $75 \mathrm{~m} M \mathrm{KCl}, 0.5 \mathrm{~m} M$ EDTA, $2 \mathrm{~m} M$ ATP and o.I $M$ sucrose. Except where otherwise stated the protein concentration varied between $0 . \mathrm{I}$ and $0.2 \mathrm{mg} / \mathrm{ml}$. The method for determining the rate of $\mathrm{O}_{2}$ uptake in a respiring system is reported elsewhere ${ }^{18}$. The incubation medium contained $I_{5} \mathrm{~m} M \mathrm{KCl}, 2 \mathrm{mM}$ EDTA, $50 \mathrm{~m} M$ Tris- $\mathrm{HCl}$ buffer, $5 \mathrm{mM} \mathrm{MgCl}_{2}$, $50 \mathrm{mM}$ sucrose and oxidizable substrate. The substrate was $60 \mathrm{~m} M$ succinate, $20 \mathrm{~m} M$ L-glutamate, or $20 \mathrm{~m} M$ pyruvate $+20 \mathrm{~m} M$ malate.

The chemicals used were obtained commercially except for the alkyldinitrophenols. These compounds were synthesized by nitration of the corresponding 4-alkylphenol according to the method described by ANSCHÜTZ AND RAUF ${ }^{19}$ for the synthesis of 2,6-dinitro-4-isoamylphenol. The alkylphenols were obtained from Fluka (Switzerland) or British Drug Houses (England).

The $\mathrm{p} K$ 's of the phenols were determined spectrophotometrically. The absorption spectra of the undissociated and the ionic form of the phenol were measured with a Cary recording spectrophotometer, Model I4. From the results the spectrum of a mixture of equal amounts of both forms was calculated, and the $\mathrm{pH}$ at which the spectrum recorded was equal to the calculated spectrum determined.

The partition coefficient $(Q)$ was estimated by equilibrating (by shaking for $3 \mathrm{~h}$ at $25^{\circ}$ ) an aqueous solution of the compound with an equal volume of xylene. The concentration of total phenol in the aqueous layer before and after the equilibration ( $c_{1}$ and $c_{2}$, respectively) was estimated spectrophotometrically, and $\mathrm{p} Q$ $\left(=-\log _{10} Q\right)$ was calculated by the equation

$$
\mathrm{p} Q=\log \frac{c_{2}}{c_{1}-c_{2}}+\log \frac{\left[\mathrm{H}^{+}\right]}{\left[\mathrm{H}^{+}\right]+K}
$$

Table I summarizes the physico-chemical constants of the compounds used. 
TABLE I

SOME PHYSICO-CHEMICAL CONSTANTS OF THE NITROPHENOLS USED

\begin{tabular}{|c|c|c|c|c|c|}
\hline \multirow[t]{2}{*}{ Compound } & \multicolumn{2}{|c|}{$\begin{array}{c}\text { Maximal absorbancy (mu) } \\
\text { in veater }\end{array}$} & \multirow{2}{*}{$\varepsilon_{m M(i o n)}$} & \multirow[t]{2}{*}{$p K$} & \multirow[t]{2}{*}{$p Q$} \\
\hline & Undissociated & Ion & & & \\
\hline$p$-Nitrophenol & 317 & 402 & 14.4 & $7.2^{\star}$ & 0.45 \\
\hline 2,4 -Dinitrophenol & 263 & 360 & I9.3 & $4 \cdot I^{\star}$ & -2.06 \\
\hline 2,6-Dinitrophenol & $35^{\circ}$ & 431 & $14 \cdot 3$ & $3.7^{\star \star}$ & -2.35 \\
\hline 3,4-Dimethyl-2,6-dinitrophenol & 362 & 428 & 5.8 & 4.2 & -3.23 \\
\hline 4-Isobutyl-2,6-dinitrophenol & 365 & 444 & 9.6 & $4 \cdot 3$ & -3.54 \\
\hline 4-Isoamyl-2,6-dinitrophenol & 368 & 446 & $7 \cdot 3$ & $4 \cdot I^{\star \star}$ & -4.15 \\
\hline 4-Isooctyl-2,6-dinitrophenol & 368 & 445 & 6.5 & $4 \cdot 1$ & -4.75 \\
\hline
\end{tabular}

* See ref. 20.

** See ref, IO.

\section{EXPERIMENTS}

As may be seen from the experiment reported in Fig. I the curves relating ATPase activity to concentration of uncoupling phenol have a maximum, i.e. there is a concentration which induces the highest ATPase activity. This concentration will be referred to as $c_{\mathrm{opt}}$. From the relative positions of the ascending slopes of the curves it can be seen that the degree of stimulatory action found at a given concentration is dependent upon the lipid solubility of the compound. The positions of the descending slopes show that the same holds true for the inhibitory action. The fact that at a fixed $\mathrm{pH}$ the ATPase activity reached by each compound at $c_{\text {opt }}$ is about the same indicates that both the stimulatory and the inhibitory action are influenced in quantitatively the same way by enhancing the lipid solubility of the uncoupling

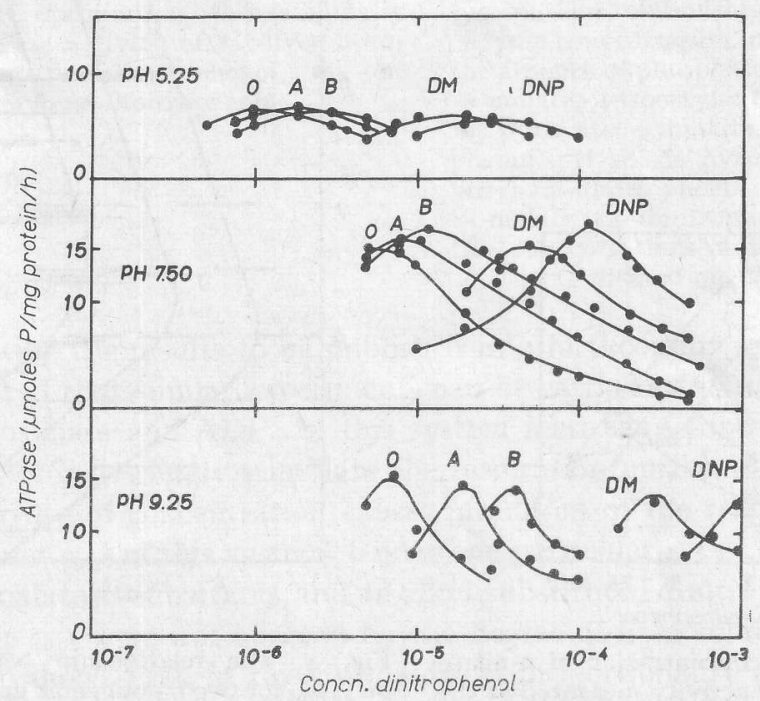

Fig. I. The effect of different concentrations of various substituted dinitrophenols on the ATPase activity of rat-liver mitochondria at $\mathrm{pH} 5.25,7.50$ and 9.25. O, 4-isooctyl-2,6-dinitrophenol; A, 4-isoamyl-2,6-dinitrophenol; B, 4-isobutyl-2,6-dinitrophenol; DM, 3,4-dimethyl-2,6-dinitrophenol; DNP, 2,6-dinitrophenol. 
phenol. The result is that a small concentration of a lipid-soluble compound has the same effect as a larger concentration of a less lipid-soluble compound. This suggests that the concentration of a phenol determining the ATPase activity is not the concentration in the aqueous phase (the medium) but the concentration in a lipid phase within the mitochondrion or the concentration in a mitochondrial compartment which is a direct reflection of that in the mitochondrial lipid. Thus, whatever the mechanism of stimulation and inhibition by uncoupling phenols might be, the active concentration at $c_{\text {opt }}$ of the uncoupling phenol appears in some way to be critical
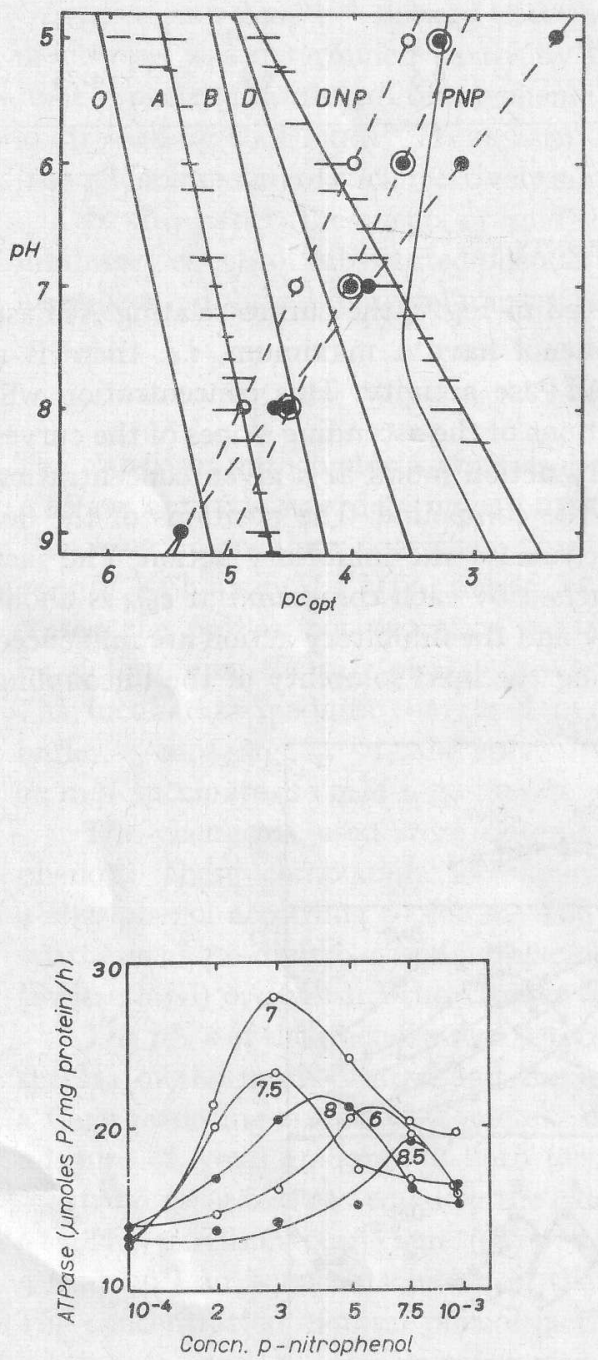

Fig. 3. The effect of concentration of $p$-nitrophenol on the ATPase activity measured at the different $\mathrm{pH}$ 's shown.
Fig. 2. The relationship between $\mathrm{pH}$ and $\mathrm{p} c_{\mathrm{opt}}$ for various nitrophenols. The full lines give the relationship between $\mathrm{p}\left(c_{\mathrm{aq}}\right)$ opt and $\mathrm{pH}$, the symbols indicating the phenol as in Fig. I, and $p$-nitrophenol. The possible error in the determination of the slope of these lines is indicated, for 4-isoamyl-2,6-dinitrophenol and 2,6-dinitrophenol, by the short horizontal lines, which show the region in which the maximum concentration must lie, as determined by activityconcentration curves of the type illustrated in Fig. I. The dotted line shows the relationship between $\mathrm{p}\left(c_{1}\right)_{\text {opt }}$ and $\mathrm{pH}$ : - -- , alkyl2,6-dinitrophenols $\left(\mathrm{p}\left(c_{1}\right)_{\text {opt }}=0.76 \mathrm{pH}-\mathrm{I} .53\right)$; $0---\mathrm{O}$, unsubstituted dinitrophenols $\left(\mathrm{p}\left(c_{1}\right)_{\text {opt }}\right.$ $=0.47 \mathrm{pH}+0.60) ; 0-\cdots, 0, p$-nitrophenol $\left(\mathrm{p}\left(c_{1}\right)_{\mathrm{opt}}=0.47 \mathrm{pH}+\mathbf{1} .50\right)$.

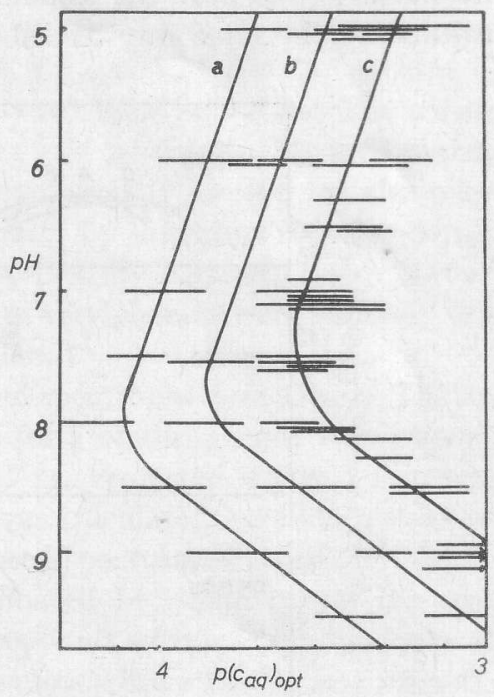

Fig. 4. The relationship between $\mathrm{pH}$ and $\mathrm{p}\left(c_{\mathrm{aq}}\right)$ opt for two halophenols and $p$-nitrophenol. a, 2,6-dibromophenol $(\mathrm{p} K=8.0)$; b, 2,6-dichlorophenol $(\mathrm{p} K=7.8)$; c, p-nitrophenol $(\mathrm{p} K=7.2)$. The horizontal lines have the same significance as in Fig. 2. 
for the mechanism and thus must be a better reflection of the situation within the mitochondrion than is the amount of phenol added.

Figs. 2-4 describe the relationship between $c_{\text {opt }}$ and $\mathrm{pH}$ for a range of phenols of different $\mathrm{p} K$ and $\mathrm{pQ}$. It is apparent from Figs. 2 and 4 that the relationship between $\mathrm{p} c_{\text {opt }}$ and $\mathrm{pH}$ may be described by a straight line, which changes its slope when the $\mathrm{pH}$ of the medium equals the $\mathrm{p} K$ of the phenol.

The $\mathrm{pH}$ optimum of the maximally stimulated ATPase is shown in Fig. 5. At each $\mathrm{pH}$ the ATPase activity was tested at three concentrations of the dinitrophenol, chosen close to the concentration which might be expected to evoke a maximum stimulation of the ATPase. The highest of the three ATPase activities thus found was considered as the maximum activity obtainable at that $\mathrm{pH}$. The same $\mathrm{pH}$ optimum, viz. 6.8, was obtained with the two dinitrophenols tested.

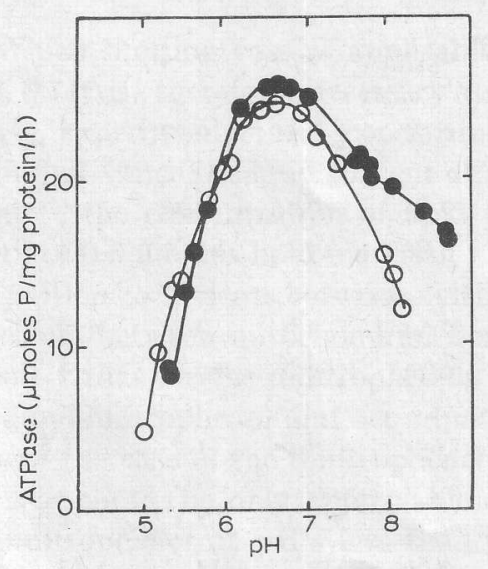

Fig. 5. The pH optimum of the maximally stimulated ATPase activity of rat-liver mitochondria. O-O, 2,6-dinitrophenol; 4-isoamyl-2,6-dinitrophenol.

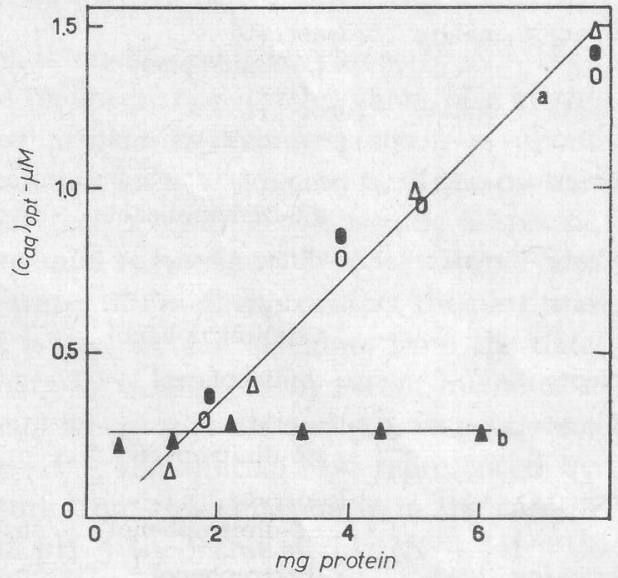

Fig. 6. The relationship between $\left(\epsilon_{\mathrm{aq}}\right)_{\text {opt }}$ and enzyme concentration in a respiring system, in the absence of phosphate or ADP. O, pyruvate + malate, 4-isooctyl-2,6-dinitrophenol, pH 5; - pyruvate + malate, 4-isooctyl-2,6-dinitrophenol, $\mathrm{pH} 7 ; \Delta$, pyruvate + malate, 4-isobutyl-2,6-dinitrophenol, $\mathrm{pH} 7 ; \mathbf{\Lambda}$, pyruvate + malate, 2,6-dinitrophenol, $\mathrm{pH} 7$ (in this case the concentrations are Ioo times those indicated on the ordinate).

Anticipating the results to be published in a forthcoming paper (see also ref. I) it may be stated that similar experiments can be carried out with a respiring system devoid of phosphate and ADP. In this system increasing concentrations of an uncoupling phenol increasingly stimulate the respiration until a maximum is reached; a further increase of concentration causes inhibition of the respiration. Thus, there is also a distinct $c_{\text {opt }}$ in this system. Under one particular set of conditions, viz. with pyruvate + malate as substrates, and an alkyl-substituted dinitrophenol as uncoupler, the values for $c_{\text {opt }}$ were not affected by the degree of lipid solubility of the dinitrophenol. Fig. 6 shows that, in this case, a direct proportionality appears between the amount of mitochondrial material added and the $c_{\text {opt }}$. Table II shows that this relationship was absent in all cases where a correlation between $c_{\text {opt }}$ and the lipid solubility does exist, viz. with pyruvate as substrate and unsubstituted phenol as 
uncoupler, or with succinate or glutamate as substrate and unsubstituted or alkylsubstituted phenol as uncoupler.

\section{TABLE II}

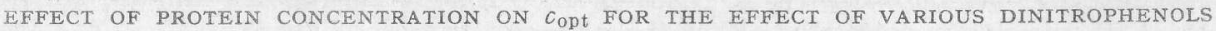
ON THE STIMULATION OF RESPIRATION

The columns marked $\times 1, \times 2, \times 3, \times 4$ give the value of $c_{\text {opt }}$ estimated in a test in which the protein content was respectively the same as, twice, three times, four times that indicated in the fourth column.

\begin{tabular}{|c|c|c|c|c|c|c|c|}
\hline \multirow[b]{2}{*}{ Substrate } & \multicolumn{3}{|l|}{ Conditions } & \multicolumn{4}{|c|}{$c_{o p t}(\mu M)$} \\
\hline & Phenol & $p H$ & $\begin{array}{l}\text { Protein content } \\
\qquad(m g / m l)\end{array}$ & $\times x$ & $\times 2$ & $\times 3$ & $\times 4$ \\
\hline Pyruvate + malate & $\begin{array}{l}\text { 4-isooctyl- } \\
\text { 2,6-dinitrophenol }\end{array}$ & 7.0 & 0.57 & 0.36 & 0.84 & - & I. $4 \mathrm{I}$ \\
\hline Pyruvate + malate & $\begin{array}{l}\text { 4-isooctyl- } \\
\text { 2,6-dinitrophenol }\end{array}$ & 5.0 & 0.57 & $0.3^{0}$ & 0.72 & - & I. 33 \\
\hline Pyruvate + malate & $\begin{array}{l}\text { 4-isobutyl- } \\
\text { 2,6-dinitrophenol }\end{array}$ & 7.0 & 0.34 & O.I5 & 0.37 & - & 0.95 \\
\hline Pyruvate + malate & 2,6-dinitrophenol & 7.0 & 0.86 & 27 & 25 & 25 & - \\
\hline Succinate & $\begin{array}{l}\text { 4-isooctyl- } \\
\text { 2,6-dinitrophenol }\end{array}$ & $7 \cdot 4$ & o. $\mathrm{I}_{4}$ & 2.6 & 2.7 & - & 2.8 \\
\hline Succinate & 2,4-dinitrophenol & $7 \cdot 4$ & o.I4 & 62 & 67 & - & 63 \\
\hline Glutamate & $\begin{array}{l}\text { 4-isooctyl- } \\
\text { 2,6-dinitrophenol }\end{array}$ & 7.2 & $0.5^{I}$ & 2.0 & I. 7 & I. 8 & - \\
\hline Glutamate & $\begin{array}{l}\text { 4-isooctyl- } \\
\text { 2,6-dinitrophenol }\end{array}$ & 6.4 & 0.66 & I.I & I.I & I. 2 & - \\
\hline Glutamate & 2,4-dinitrophenol & 7.2 & 0.60 & r3 & $r_{4}$ & I3 & 14 \\
\hline
\end{tabular}

\section{DISCUSSION}

The results summarized in Fig. I indicate that the activity of an uncoupling phenol is determined, not by the concentration of the phenol in the medium, but by the concentration in a lipid phase within the mitochondrion. Since only the former concentration is known, it is necessary to work out the relationship between the two concentrations. As model we shall assume that a small amount of lipid material is suspended in an aqueous phase, the ratio of the volumes of the two phases being $f$. When a lipid-soluble and dissociable compound is added, two equilibria will be established, first in the aqueous phase between the undissociated molecule and the phenolate ion, and secondly between the undissociated molecule dissolved in the lipid phase and in the water. The ratio between the concentrations in the two phases is given by the partition coefficient, $Q$. Putting $[\varnothing]=$ concentration of the phenol in the lipid phase; $[\varnothing \mathrm{OH}]=$ concentration of the undissociated phenol molecule in the aqueous phase; $\left[\varnothing \mathrm{O}^{-}\right]=$concentration of the phenolate ion in the aqueous phase, then the following equations can be derived:

$$
\begin{aligned}
{\left[\varnothing \mathrm{O}^{-}\right]\left[\mathrm{H}^{+}\right] } & =K[\varnothing \mathrm{OH}] \\
{[\varnothing] } & =Q[\varnothing \mathrm{OH}] \\
c & =\left[\varnothing \mathrm{O}^{-}\right]+[\varnothing \mathrm{OH}]+f[\varnothing]
\end{aligned}
$$


where $c$ is the molar concentration in the whole suspension of the phenol added, and $K$ is the dissociation constant of the phenol. Then, $\log c=\log [\varnothing]+\mathrm{p} Q+\mathrm{pH}$ $+\log \left(K+\left[\mathrm{H}^{+}\right]+f Q\left[\mathrm{H}^{+}\right]\right)$, where $\mathrm{pQ}=-\log Q$. Further, writing $-\log c$ as $\mathrm{p} c_{\mathrm{aq}}$ and $-\log [\varnothing]$ as $\mathrm{p} c_{1}$ we obtain

$$
\mathrm{p} c_{1}=\mathrm{p} c_{\mathrm{aq}}+\mathrm{p} Q+\mathrm{pH}+\log \left(K+\left[\mathrm{H}^{+}\right]+f Q\left[\mathrm{H}^{+}\right]\right)
$$

Three limiting cases of Eqn. I are useful:

(a) When $K \gg\left[\mathrm{H}^{+}\right]$and $K \gg f Q\left[\mathrm{H}^{+}\right]$

(b) When $\left[\mathrm{H}^{+}\right] \gg K$ and $f Q\left[\mathrm{H}^{+}\right] \ll\left[\mathrm{H}^{+}\right]$

$$
\mathrm{p} c_{1}=\mathrm{p} c_{\mathrm{aq}}+\mathrm{p} Q+\mathrm{pH}-\mathrm{pK}
$$

(c) When $f Q\left[\mathrm{H}^{+}\right] \gg K$ and $f Q\left[\mathrm{H}^{+}\right] \gg\left[\mathrm{H}^{+}\right]$

$$
\mathrm{p} c_{1}=\mathrm{p} c_{\mathrm{aq}}+\mathrm{p} Q
$$

$$
\mathrm{p} c_{1}=\mathrm{p} c_{\mathrm{aq}}+\log t
$$

Which limiting case is applicable depends on the relative values of $K,\left[\mathrm{H}^{+}\right]$, $f$ and $Q$. It is, therefore, necessary to make an estimation of the value of $f$ in the ATPase experiments. The concentration of protein in the suspension is about $0.13 \mathrm{mg} / \mathrm{ml}$. Since the lipid content of a mitochondrion is approx. $60 \%$ of the protein content ${ }^{21}$, the concentration of lipid is about $0.08 \mathrm{mg} / \mathrm{ml}$. If we assume a specific gravity of 0.8 for this lipid material, $f$ will be equal to about $\mathrm{IO}^{-4}$. If we assume that the partition coefficients between xylene and water of the phenols reflect the partition coefficients between mitochondrial lipid and water, we can calculate from the data of Table I that for the dinitrophenols used here $f Q$ is less than I, except in the case of isoamyldinitrophenol and octyldinitrophenol where it is I.I and 5.6, respectively. Since, in the case of the dinitrophenols, $K \gg\left[\mathrm{H}^{+}\right]$, the limiting case represented by Eqn. 2 applies. The only appreciable departure from this equation is in the case of octyldinitrophenol at $\mathrm{pH}$ 's less than 5.5 (at $\mathrm{pH} 5$ the value of $\log \left(\mathrm{K}+\left[\mathrm{H}^{+}\right]+\right.$ $f Q\left[\mathrm{H}^{+}\right]$) equals -3.8 while $\mathrm{p} K$ equals $\left.4 . \mathrm{I}\right)$. For $p$-nitrophenol, $f Q$ is equal to $10^{-4.45}$; thus $f Q\left[\mathrm{H}^{+}\right]$is negligible in comparison with $\left[\mathrm{H}^{+}\right]$, so that Eqn. 2 may be used when $\mathrm{pH}>\mathrm{p} K$ and Eqn. 3 when $\mathrm{pH}<\mathrm{pK}$.

With the aid of these equations, the $c_{1}$ corresponding to $c_{\mathrm{aq}}=c_{\mathrm{opt}}$ can be calculated. Table III lists the values of $\mathrm{p} c_{\mathrm{aq}}$ obtained for various nitrophenols at different $\mathrm{pH}$ 's, while the corresponding calculated values of $\mathrm{p}\left(c_{1}\right)_{\text {opt }}$ are given in Table IV. Several conclusions can be drawn from the results of these calculations: (a) The $\left(c_{1}\right)_{\text {opt }}$ calculated is the same within the homologous group of alkyl-2,6-dinitrophenols.

(b) There is a linear relationship between $\left(c_{1}\right)_{\text {opt }}$ and $\mathrm{pH}$ (see the dotted lines in Fig. 2).

(c) The value of $\left(c_{1}\right)_{\text {opt }}$ is not only dependent upon the lipid solubility of the phenol,

TABLE III

THE VALUES OF $\mathrm{p}\left(c_{\mathrm{aq}}\right)$ opt FOR VARIOUS NITROPHENOLS AT DIFFERENT $\mathrm{pH}$ 'S

The values are calculated from Fig. I.

\begin{tabular}{llllll}
\hline \multicolumn{1}{c}{ Uncoupling agent } & $p H_{5}$ & $p H_{6}$ & $p H_{7}$ & $p H^{8}$ & $p H_{9}$ \\
\hline p-Nitrophenol & 3.30 & 3.37 & $3.5 \mathrm{I}$ & 3.39 & - \\
2,6-Dinitrophenol & 4.77 & 4.22 & 3.68 & 3.12 & - \\
3,4-Dimethyl-2,6-dinitrophenol & 4.92 & $4.5 \mathrm{I}$ & 4.36 & 3.95 & 3.60 \\
4-Isobutyl-2,6-dinitrophenol & 5.16 & 4.88 & 4.71 & 4.48 & 4.26 \\
4-Isoamyl-2,6-dinitrophenol & 5.55 & 5.42 & 5.18 & 4.92 & 4.71 \\
4-Isooctyl-2,6-dinitrophenol & 6.08 & 5.89 & 5.64 & $5.4 \mathrm{I}$ & 5.24 \\
\hline
\end{tabular}


as there is a substantial difference between $\left(c_{1}\right)_{\text {opt }}$ for the substituted and the nonsubstituted nitrophenols.

The linear relationship between $\left(c_{1}\right)_{\text {opt }}$ and $\mathrm{pH}$, together with the change in the relationship between $c_{1}$ and $c_{\mathrm{aq}}$ which occurs when the $\mathrm{pH}$ is near the $\mathrm{p} K$ of the phenol tested, accounts for the bends in the $\left(c_{\mathrm{aq}}\right)$ opt-pH curves shown for $p$-nitrophenol, dichlorophenol and dibromophenol in Fig. 4. This finding and the constancy of $\left(c_{1}\right)_{\text {opt }}$ within the series of alkyl-dinitrophenols tested are strong evidence in support of the assumptions leading to Eqn. I and to the two limiting cases represented by Eqns. 2 and 3 .

\section{TABLE IV}

THE VALUES OF $\mathrm{p}\left(c_{1}\right)_{\text {opt }}$

The values are calculated from the values in Table III as indicated in the text.

\begin{tabular}{llllll}
\hline \multicolumn{1}{c}{ Uncoupling agent } & $p H_{5}$ & $p H_{6}$ & $p H 7$ & $p H^{8}$ & $p H_{9}$ \\
\hline p-Nitrophenol & & & & & \\
2,6-Dinitrophenol & 3.55 & 3.62 & 4.06 & 4.62 & - \\
3,4-Dimethyl-2,6-dinitrophenol & 3.72 & 4.17 & 4.63 & 5.05 & 5.16 \\
4-Isobutyl-2,6-dinitrophenol & 2.48 & 3.07 & 3.82 & 4.51 & 5.43 \\
4-Isoamyl-2,6-dinitrophenol & 2.33 & 3.05 & 3.88 & 4.65 & 5.56 \\
4-Isooctyl-2,6-dinitrophenol & 2.30 & 3.04 & 3.93 & 4.67 & 5.44 \\
& 2.28 & 3.09 & 3.84 & 4.61 & \\
\hline
\end{tabular}

There is evidence that the third limiting case, expressed by Eqn. 4, is also representative of a real situation. This equation may be written $c_{1}=c_{\mathrm{aq}} / f$. Since $f$ is proportional to the amount of mitochondria added, we can also express this equation in the following way: with a very lipid-soluble compound the concentration in the mitochondrial lipid (assumed to be the concentration determining the activity) is directly proportional to the amount of the compound added $\left(c_{\mathrm{aq}}\right)$ and inversely proportional to the amount of mitochondria added. In this case, the active concentration is best represented by the amount of compound added expressed per milligram mitochondrial material, rather than by the concentration of the compound in the medium. It is known that this is the case with the highly lipid-soluble compounds antimycin $^{22}$ and oligomycin ${ }^{23}$.

As will be discussed in detail in another paper, the $c_{\text {opt }}$ obtained for a respiring system with pyruvate + malate as substrate does not depend upon the size of the alkyl substituent in a series of alkyldinitrophenols (cf. isobutyl- and isooctyldinitrophenol at similar protein concentration in Table II). Two explanations are possible: (a) The model represented by Eqn. I does not apply to this situation. (b) The model is correct, but is represented by its third limiting case (Eqn. 4) in which $p Q$ does not appear, but $\log f$ does. Table II shows that indeed the disappearance of the relationship between $\mathrm{p} c_{\mathrm{aq}}$ and $\mathrm{p} Q$ goes hand in hand with the establishment of a relationship between $\mathrm{p} c_{\mathrm{aq}}$ and $f$. This would be a most unlikely coincidence if $c_{\mathrm{aq}}$ had to be considered as the effective concentration. This provides further support in favour of the model proposed and of the assumptions made.

This has important consequences for the evaluation of the $\mathrm{pH}$-activity curves of the ATPase. From Fig. 2 it will be clear that any concentration of dinitrophenol between $2 \cdot 10^{-5} M$ and $2 \cdot 10^{-3} M$ tested at a series of $\mathrm{pH}$ 's will have one optimum at the $\mathrm{pH}$ where the dinitrophenol concentration chosen happens to be $c_{\text {opt }}$, and another 
optimum or a "shoulder" at the real pH optimum of the ATP-splitting enzyme system. This accounts for the $\mathrm{pH}$ optima of 8.5 and 6.3 found by Myers AND SLATER ${ }^{14}$ when using dinitrophenol concentrations between $\mathrm{IO}^{-5} \mathrm{M}$ and $\mathrm{IO}^{-3} \mathrm{M}$. That the $\mathrm{pH}$ might have an effect upon the concentration of the active form of the uncoupling phenol was a possibility recognized by MYERS AND SLATER but rejected because of the results of experiments with p-nitrophenol. p-Nitrophenol ( $\mathrm{p} K$ 7.2) and 2,4-dinitrophenol $(\mathrm{pK}$ 4.I) are about equally effective at $\mathrm{pH} 7$ in inducing ATPase activity in rat-liver mitochondria. Without taking into account the effect of lipid solubility this seems to exclude a role for the undissociated phenol molecule, since the concentration of the undissociated $p$-nitrophenol molecule under these circumstances is about 480 times as large as the concentration of the undissociated 2,4-dinitrophenol. From Table I we can see that the lipid solubility of 2,4-dinitrophenol is about 320 times as great as that of $p$-nitrophenol. Thus the difference of the concentration of the undissociated phenol molecule in the aqueous phase is largely counteracted by the difference in lipid solubility, resulting in approximately equal concentrations in the lipid phase. The pH-activity curve of the maximally stimulated ATPase of fresh rat-liver mitochondria is shown in Fig. 5 .

\section{ACKNOWLEDGEMENTS}

I am very grateful to Prof. Dr. E. C. SLATER for his interest and advice, to Dr. W. C. HüLsmann for many helpful suggestions and discussions, and to Miss M. VAN UFFELEN for skilful technical assistance.

This work was supported in part by Research Grant RG 6569 of the U.S. Public Health Service. The Cary recording spectrophotometer was purchased with the help of a grant made available by the Rockefeller Foundation.

\section{REFERENCES}

1 H. C. HEMKER, Het Mechanisme van de Werking van Ontkoppelende fenolen op de Ademhalingsketenfosforylering, M.D. Thesis, University of Amsterdam, I962. 2 H. H. Meyer and R. Gottlieb, Die Experimentelle Pharmakologie, Urban and Schwarzenberg,
Berlin-Wien, 1910, p. 89.

3 L. Ernster, O. Jalling, H. Löw and O. Lindberg, Exptl. Cell Research, Suppl., 3 (I955) I24.

4 O. Jalling, O. Lindberg and L. Ernster, Acta Chem. Scand., 9 (I955) Ig8.

5 E. G. Ball, C. B. Anfinsen and O. Cooper, J. Biol. Chem., I68 (1947) 257.

6 A. L. TAPpel, J. Biochem. Pharmacol., 3 (I960) 289.

7 C. Martius and D. Nitz-Litzow, Biochim. Biophys. Acta, I2 (I953) 134.

8 C. Martius and D. Nitz-Litzow, Biochem. Z., 327 (I955) I.

9 W. N. Aldridge, Biochem. J., 69 (1958) 367.

10 W. C. Hülsmann, Over het Mechanisme van de Ademhalingsketenphosphorylering, M.D. Thesis, Poortpers, N.V., Amsterdam, I958.

11 E. GLadtKe AND E. Liss, Biochem. Z., 33i (I959) 65.

12 E. Liss, Acta Biol. Germ., I (I958) 373.

13 H. A. Lardy, Proc. 3rd Intern. Congr. Biochem., Brussels, 1955, Academic Press, New York, I 956, P. 287.

14 D. K. Myers and E. C. Slater, Biochem. J., 67 (I957) 558, 572.

15 R. H. DE DeKen, Biochim. Biophys. Acta, I7 (I955) 494.

16 V. H. Parker, Biochem. J., 69 (I958) 306.

17 H. C. Hemker and W. C. Hülsmann, Biochim. Biophys. Acta, 48 (I96I) 22 I

18 H. C. Hemker, Biochim. Biophys. Acta, 60 (1962) 646.

19 R. Anschütz and G. Rauf, Ann. Chem., Liebigs, 327 (1903) 2 I I.

${ }^{20} \mathrm{~L}$. PAuling, The Nature of the Chemical Bond, Cornell University Press, Ithaca, 1940.

21 G. V. Marinetti, D. J. Scaramuzzino and E. Stotz, J. Biol. Chem., 224 (r957) 8ig.

22 V. R. Potter and A. E. Reif, J. Biol. Chem., I94 (I952) 287.

${ }^{23}$ E. C. Slater, personal communication. 